\title{
Effectiveness of an Educational Program on Orthopedic Nurses' Knowledge Concerning Pin Track Infection of External Fixation in Al-Emamin AL- Khadamin Medical City.
}

\author{
Thair R. Bader, MSc. ${ }^{1}$, Dr. Hussein H. Atiyah, $\mathrm{PhD}^{2}$ \\ ${ }^{1}$ (Academic Nurses, Adult Nursing Department, College of Nursing, University of Bagdad, Iraq) \\ 2 (Assistant Professor, Adult Nursing Department, College of Nursing, University of Bagdad, Iraq)
}

\begin{abstract}
Background: pin external infection is the most common health problem of nosocomial infection of patients their suffers from exogenous or endogenous symptoms of pin fixation infection. While pin skeletal fixation was considered a surgical treatment technique for orthopaedic patient to treat fracture bone which occur result direct internal trauma or external trauma in orthopaedic ward. But in sufficient orthopaedic nursing care of external pin track lead to infection occur around pin hole and transmission of microbes to the bone causing ununion bone site fracture, loosen of rigid pin, abscess, sever painful and osteomyelitis. This problem was effecting on the quality of life of orthopaedic patient.

Objectives: The study aims to determine the effect of an educational program on knowledge of orthopaedic nurses for pin external fixation and to find out the relationship between nurses' socio-demographic characteristics of gender, age, educational level, marital status and their knowledge related pin track infection for external fixation.

Methodology: A descriptive analytic study was conduct on Non-probability(purposive sample)of (40) an orthopaedic nurses ; (20) orthopaedic nurses for the study group and (20) orthopaedic nurses for the control group, who had work in orthopaedic ward at AL- Emamin AL-Kadhumian teaching city in Baghdad city. A questionnaires form was used a tool of data collection for the study and control groups in the pretest from the period (24 th of May 2016 to $5^{\text {th }}$ June 2017) which these data are introduce through the application of an educational program. Then after three weeks was given the post test to study and controls groups, after the educational program has been finished with the study group for same questionnaires that used in the pretest. Descriptive and inferential statistics analysis were used to analyzed the data.

Results: The results of the orthopaedic nurses knowledge study group showed there are differences between their knowledge about pin track infection in pretest and their orthopaedic nurses knowledge in posttest periods. That there was a statistically no significant association at $(P \leq 0.05)$ between the study group of pin track infection of orthopaedic nurses knowledge related to( age, gender, ,marital status) but there was a significant association related to the educational level .

Conclusion: the results concludes defect and insufficient of orthopaedic nurses knowledge related pin external fixation were used to treated fractures bones for orthopaedic patients in ward. But the results of the study group of orthopaedic nurses knowledge which is exposed to the educational program benefited from the implementation of the educational program, and their knowledge was successfully enhanced and established. Recommendation: The study recommended the significance of increasing awareness among orthopaedic nurses about pin external fixation knowledge distributed through a handbooks, explanatory posters, and performing an educational health programs through modern technological to all orthopaedic nurses that include specific training session. Finally, the researchers suggest performing further new studies that include a larger sample which include knowledge and practices for all methods treatment internal and external fixation techniques Keywords: Effectiveness, Educational Program, Orthopaedic Nurses, Pin External Fixation, Infection.
\end{abstract}

\section{Introduction}

A pin track infection is a clinical syndrome caused by the transmission of micro organism pathogen from exogenous the percutaneously skin place attached to the external pin fixation device and cross to the bone ${ }^{[1]}$. Microorganisms are mean causing of infection in orthopaedic ward and entrance to musculoskeletal system of the body human from direct include; introduction through supportive management such as the skin (a pin track, stab wound, injection, laceration and open wound fracture or operation). Direct spread from a Contiguous focus of pin infection or indirect spread via the blood stream such as nose, mouth, respiratory, digestive and urinary system ${ }^{[2]}$. Over $70 \%$ Staphylo coccus aureus bacterial infection is causing inflammation of orthopaedic pin external cases in ward. Reside pin sepsis was a high rate dilemma caused by group A Betahaemolytic Streptococcus and Alpha-Haemolytic Diplococcus in muscoskeletal system ${ }^{[3]}$. Pin track infection occur (5\%-10\%) of open wound fracture of people ,tibia and femoral and pin track infection occur (0.5\%-42\%) 
treated with external fixation, orthopaedic pin track infection have been prolong time hospital stays an average of 2 weeks rate ; add to increase costs more than $300 \%{ }^{[4]}$. Annual incidence of infection in pin stainless for external fixation in united states approximately $1.07 \%$, with 8000 deaths directly related infection and cost $10 \$$ but united kingdom cost $2500 \$$ add increase hospitalization between 17 extra days these are causes morbidity and mortality ${ }^{[5]}$. Infection pin track complications of external fixation in Iraq divided; $40 \%$ major complication include infection, osteomyelitis, ununion bone site of fracture, loss of alignment, failure of surgery, and about $60 \%$ suffer from minor pin site complication of external fixation include continue pain and loosen of pin site fixation ${ }^{[6]}$.

\section{Methodology}

A Quisi- experimental design used to complete the early stated objective. The study of educational program was done from (24 $4^{\text {th }}$ of May 2016 to $5^{\text {th }}$ June 2017).A purposive (Non-probability) sample of (40) orthopaedic nurses; (20 orthopaedic nurses in the control group and 20 orthopaedic nurses in the study group) who had done in orthopaedic ward in Al-Emamin AL- Khadamin medical city . The data were collected of The preliminary assessment was carried out during the period from (May $2^{\text {nd }}$ to june $10^{\text {th }}$ 2016). The researcher collected the samples by introduced to the orthopaedic nurses pre implement the educational program before test was done for both (study and control group) related to orthopaedic nurses knowledge concerning pin track infection for external fixation and the researcher used a questionnaire format for orthopaedic nurses knowledge. Three weeks later, the post-test was given to both groups, after the program has been finished with the study group. The researcher using the most recent and relevant literature with posters through applicable educational program. Questionnaire form filled by the orthopaedic nurses. Questionnaires form consists of two parts ; the first part is about the socio-demographic data information of orthopaedic nurses; the second part is about involves orthopaedic nurses knowledge about pin track infection for external fixation .The content validity of the questionnaire form was recognized through displaying it on (30) experts with competence and the reliability have been determine through the pilot study and the application of the Pearson correlation coefficient the methods of descriptive and inferential statistics are used when the data have been analyze.

\section{Results}

Table (1): socio-demographic Data characteristics of orthopaedic nurses

\begin{tabular}{|c|c|c|c|c|}
\hline \multirow{2}{*}{$\begin{array}{l}\text { Variables } \\
\text { Gender }\end{array}$} & \multicolumn{2}{|c|}{ Study Group } & \multicolumn{2}{|c|}{ Control Group } \\
\hline & Frequency & Percentage & Frequency & Percentage \\
\hline Male & 12 & 60 & 12 & 60 \\
\hline Female & 8 & 40 & 8 & 40 \\
\hline Age (Years) & Frequency & Percentage & Frequency & Percentage \\
\hline $20-29$ & 5 & 25 & 4 & 20 \\
\hline $30-39$ & 7 & 35 & 10 & 50 \\
\hline $40-49$ & 4 & 20 & 4 & 20 \\
\hline 50 and above & 4 & 20 & 2 & 10 \\
\hline Marital status & Frequency & Percentage & Frequency & Percentage \\
\hline Married & 15 & 75 & 12 & 60 \\
\hline Single & 3 & 15 & 6 & 30 \\
\hline Divorced & 1 & 5 & 0 & 0 \\
\hline Widowed & 1 & 5 & 2 & 10 \\
\hline Level of education & Frequency & Percentage & Frequency & Percentage \\
\hline Nursing School & 1 & 5 & 7 & 35 \\
\hline $\begin{array}{l}\text { Secondary Nursing } \\
\text { School }\end{array}$ & 7 & 35 & 0 & 0 \\
\hline Nursing Institute & 2 & 10 & 3 & 15 \\
\hline Medical Institute & 6 & 30 & 6 & 30 \\
\hline Academic Nurse & 4 & 20 & 4 & 20 \\
\hline
\end{tabular}

Table (1): Socio-demographic Data characteristics analysis of orthopaedic nurses shows that the majority of $(60 \%)$ were female for the study group and $(60 \%)$ were male and $(40 \%)$ were female in control group. Most of the study group (35\%) from the age group (30-39) years and (20-29)(25\%) for study group and (50\%)from the age group (30-39) years and(20\%) for (20-29)(40-49) years for the control group. The majority of (75\%) were married of the study group and (60\%) were married of the control group. Relative to their level of education ,the majority of number of them were secondary nursing school graduated(35\%) and(30\%) were medical nursing institute these for the study group .While (35\%)were nursing school graduated for the control group. 
Table ( 2 ): Mean of Score Comparison of pre-test between the Study and Control Groups of pin infection

\begin{tabular}{|c|l|c|c|c|c|}
\hline \multicolumn{2}{|l|}{$\begin{array}{l}\text { Orthopaedic Nurses knowledge concerning pin track infection of } \\
\text { external fixation }\end{array}$} & \multicolumn{2}{|c|}{ Study Group } & \multicolumn{2}{c|}{ Control Group } \\
\cline { 3 - 5 } \multicolumn{2}{|l}{} & $\begin{array}{c}\text { Mean } \\
\text { of } \\
\text { score. }\end{array}$ & $\begin{array}{c}\text { Standard } \\
\text { deviation }\end{array}$ & $\begin{array}{c}\text { Mean of } \\
\text { score. }\end{array}$ & $\begin{array}{c}\text { Standard } \\
\text { deviation }\end{array}$ \\
\hline 1. & $\begin{array}{l}\text { Pin track infection is the condition in which the microorganisms } \\
\text { invades the body tissues around pin hole during the insertion } \\
\text { process }\end{array}$ & 2.50 & 0.82 & 2.40 & 0.75 \\
\hline 2. & $\begin{array}{l}\text { Pin track infection is the condition in which the host } \\
\text { (orthopaedic patient) physiological and immunological defenses } \\
\text { interact with the infection }\end{array}$ & 1.90 & 0.85 & 1.65 & 0.67 \\
\hline 3. & $\begin{array}{l}\text { Pin track infection for external fixation occur a result of the } \\
\text { direct contact of orthopaedic patient with aseptic instruments. }\end{array}$ & 1.50 & 0.60 & 1.50 & 0.68 \\
\hline 4. & $\begin{array}{l}\text { Spill medical devices connected has orthopaedic patients such } \\
\text { as (folly catheter, body secretion ,drains and chest tubes ) are } \\
\text { major sources of pin track infection }\end{array}$ & 1.60 & 0.68 & 1.45 & 0.67 \\
\hline 5. & $\begin{array}{l}\text { Pin track infection for external fixation diagnosis can be } \\
\text { determined through examining the local signs and symptoms }\end{array}$ & 1.25 & 0.44 & 1.10 & 0.30 \\
\hline 6. & $\begin{array}{l}\text { Hyperthermia is a major indicator of pin track infection for } \\
\text { external fixation }\end{array}$ & 1.15 & 0.37 & 1.05 & 0.22 \\
\hline 7. & $\begin{array}{l}\text { Pin track infection can be diagnosed by losing the function of } \\
\text { the affect part of the body }\end{array}$ & 1.70 & 0.65 & 1.40 & 0.50 \\
\hline 8. & $\begin{array}{l}\text { Endogenous infection sources can be causes pin track infection } \\
\text { of external fixation }\end{array}$ & 1.30 & 0.47 & 1.55 & 0.61 \\
\hline 9. & $\begin{array}{l}\text { Swelling ,redness, pus secretion are signs and symptoms of } \\
\text { infection pin track }\end{array}$ & 1.55 & 0.68 & 1.90 & 0.79 \\
\hline 1 & $\begin{array}{l}\text { Crusts ,redness, fever are an infection indicators of pin track } \\
\text { infection }\end{array}$ & 1.35 & 0.58 & 1.35 & 0.58 \\
\hline
\end{tabular}

Table (2): The results of the orthopaedic nurses' knowledge study group and control group showed there are differences between mean of score of pre-test for orthopaedic nurses knowledge related of pin track infection of external fixation, low rates. In item one was high rate of both groups only.

Table ( 3 ): Mean of Score Comparison of posttest between the Study and Control Groups of pin infection

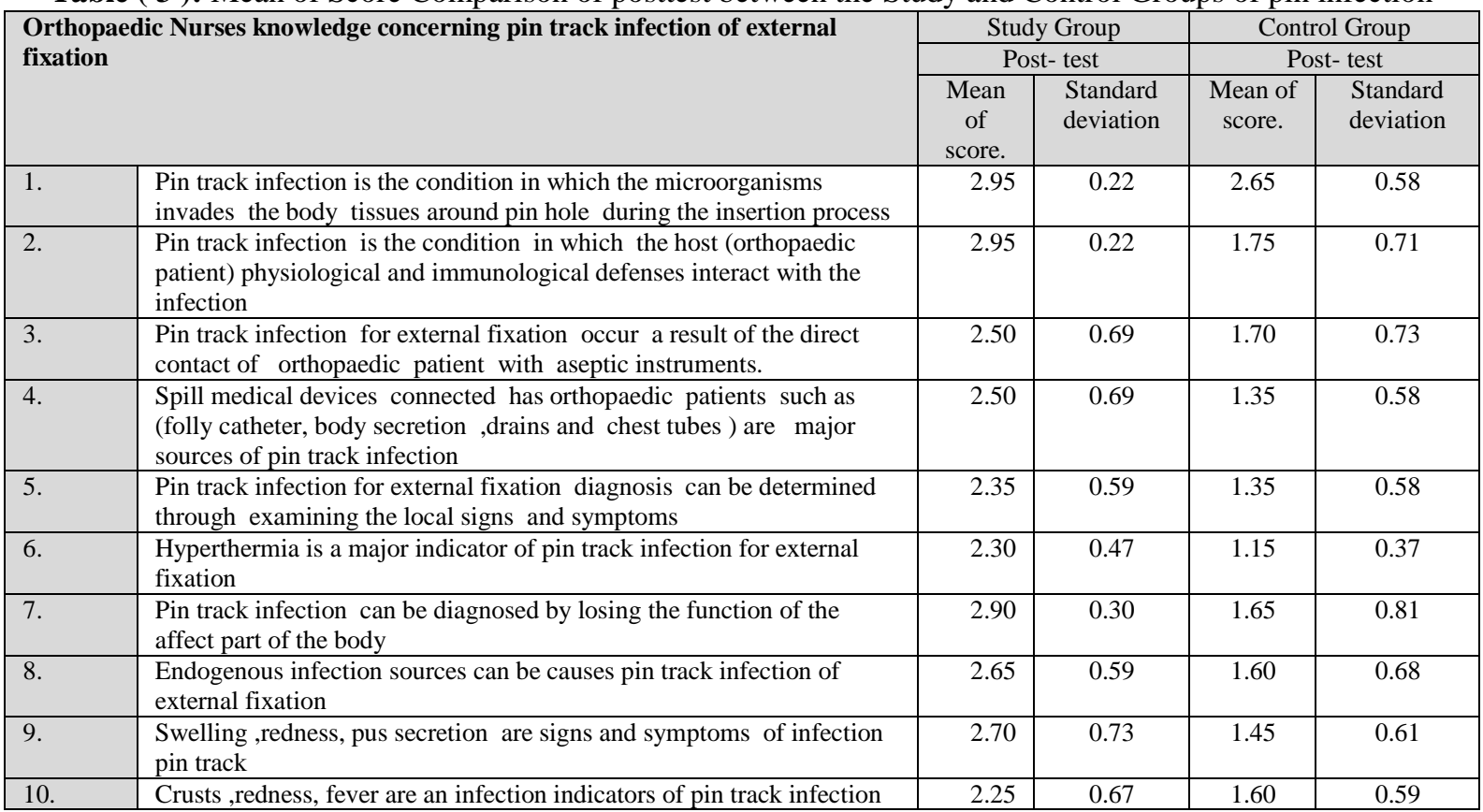

Table (3): The results of the orthopaedic nurses' knowledge study group shows that mean of score of post-test for orthopaedic nurses knowledge related of pin track infection of external fixation, different between mean of score of study and control groups. Items were high rates of study group for post- test, In item one was high rate of both groups . 
Table(4) Mean of Score Comparison of pretest and posttest between the Study Groups of pin infection

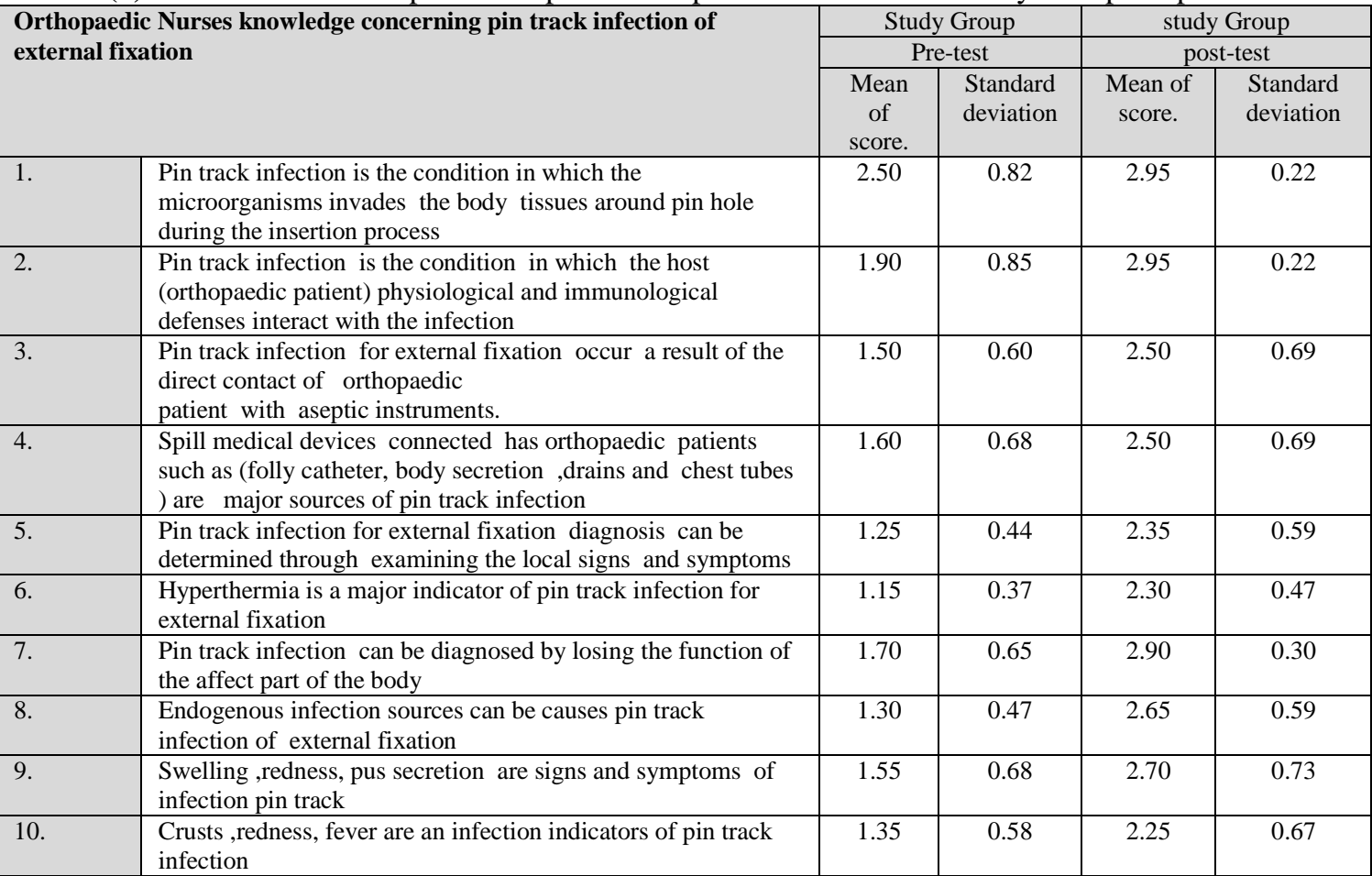

Table (4):The results of the orthopaedic nurses' knowledge study group showed there are differences between mean of score of pre-test and post-test for orthopaedic nurses knowledge related of pin track infection of external fixation. In items were high rate of post- test for study group but low rate in pre-test for study group.

Table (5)Association between the study group's Age and their knowledge total items rate in the post test

\begin{tabular}{|l|c|c|c|}
\hline \multirow{2}{*}{ Age (Years) } & Total items rate of orthopaedic nurses knowledge for the study group posttest & \multirow{2}{*}{ Total } \\
\cline { 2 - 4 } & Moderate & High & 5 \\
\hline $20-29$ & 0 & 5 & 7 \\
\hline $30-39$ & 1 & 6 & 4 \\
\hline $40-49$ & 0 & 4 & 4 \\
\hline 50 and above & 0 & 3 & 20 \\
\hline Total & 1 & 18 & $x^{2}$ obs. 0.991 \\
\hline \multicolumn{2}{|c|}{$x^{2}$ crit. $=7.815$} & P $\leq 0.05$ & \\
\hline
\end{tabular}

$\mathrm{Df}=$ degree of freedom, $x^{2}$ crit=chi-squire critical, $\mathrm{P}=$ probability, $x^{2}$ ob $=$ Chi- Squire Observed

Table(5) :shows that there is no significant difference between age and total items rate of orthopaedic nurses knowledge related to pin track infection for external fixation for the study group post-test.

Table (6) Association between the study group's Gender and their knowledge total items rate in the post test

\begin{tabular}{|l|c|c|c|}
\hline \multirow{2}{*}{ Gender } & Total items rate of orthopaedic nurses knowledge for the study group & \multirow{2}{*}{ Total } \\
\cline { 2 - 3 } & Moderate & High & 12 \\
\hline Male & 11 & 1 & 8 \\
\hline Female & 7 & 0 & 20 \\
\hline Total & 18 & 1 & $x^{2}$ obs. 0.814 \\
\hline \multicolumn{2}{|c|}{$x^{2}$ crit. $=3.841$} & $\mathrm{P} \leq 0.05$ & \\
\hline
\end{tabular}

$\mathrm{Df}=$ degree of freedom, $x^{2}$ crit=chi-squire critical, $\mathrm{P}=$ probability, $x^{2}$ ob $=$ Chi- Squire Observed

Table(6): shows that there is no significant difference between gender and total items rate of orthopaedic nurses knowledge related to pin track infection for external fixation for the study group post-test.

Table (7) Association between the study group's Mitral status and their knowledge total items rate in the post test

\begin{tabular}{|l|c|c|c|}
\hline \multirow{2}{*}{ Mitral status } & Total items rate of orthopaedic nurses knowledge for the study group posttest & \multirow{2}{*}{ Total } \\
\cline { 2 - 4 } & Moderate & High & 15 \\
\hline Married & 13 & 1 & 3 \\
\hline Single & 3 & 0 & 1 \\
\hline Widowed & 1 & 0 & 1 \\
\hline Divorced & 1 & 0 & \\
\hline
\end{tabular}


Effectiveness of an Educational Program on Orthopedic Nurses' Knowledge Concerning Pin Track

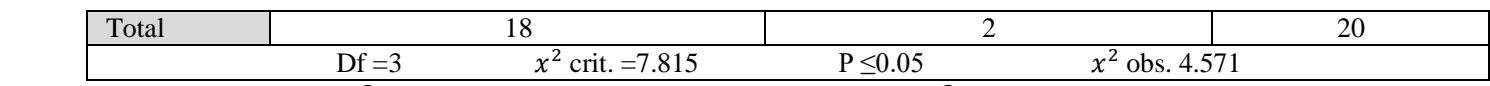

$\mathrm{Df}=$ degree of freedom,$x^{2}$ crit=chi-squire critical, $\mathrm{P}=$ probability, $x^{2}$ ob $=$ Chi- Squire Observed

Table(7) :shows that there is no significant difference between mitral status and total items rate of orthopaedic nurses knowledge related to pin track infection for external fixation for the study group post-test.

Table (8) Association between the study group's Educational level and their knowledge total items rate in the post test

\begin{tabular}{|c|c|c|c|}
\hline \multirow[t]{2}{*}{ Educational level } & \multicolumn{2}{|c|}{$\begin{array}{c}\text { Total items rate of orthopaedic nurses knowledge for the study group } \\
\text { posttest }\end{array}$} & \multirow[t]{2}{*}{ Total } \\
\hline & Moderate & High & \\
\hline Nursing School & 0 & 0 & 0 \\
\hline $\begin{array}{l}\text { Secondary Nursing } \\
\text { School }\end{array}$ & 1 & 6 & 7 \\
\hline Nursing Institute & 0 & 2 & 2 \\
\hline Medical Institute & 0 & 6 & 6 \\
\hline Academic Nursing & 0 & 4 & 4 \\
\hline Total & 1 & 18 & 20 \\
\hline & $x^{2}$ crit. 9.488 & $x^{2}$ obs. 11.37 & \\
\hline
\end{tabular}

$\mathrm{Df}=$ degree of freedom, $x^{2}$ crit=chi-squire critical, $\mathrm{P}=$ probability, $x^{2}$ ob $=$ Chi- Squire Observed

Table(8): shows that there is a significant difference between educational level and total items rate of orthopaedic nurses knowledge related to pin track infection for external fixation for external fixation for the study group post-test.

\section{Discussion}

Discussion of orthopaedic nurses socio-demographic characteristics of the studied sample( Table 1):

Throughout the course of the present study, it has been noticed that approximately the highest proportion of the study sample $(60 \%)$ were orthopaedic nurses males equally for control and study group , the researcher noticed orthopaedic nurses men more than orthopaedic nurses women were worked in the orthopaedic ward. The results were similar to a study done by Jadranaka, et a $1 .{ }^{(7)}$ who showed that majority (70\%)of orthopaedic nurses males staff in orthopaedic ward. Through the data analysis distribution of demographic variables, its appear from table(1) that the age groups were frequently from (30-39) years their mean age range was $(35 \%)$ for the orthopaedic nurses knowledge of pin track external fixation of study group, and for the control group the age of (30-39) years their mean range was $(50 \%)$.this result disagree with that Walker,2012 $\left({ }^{8)}\right.$ who showed that the highest proportion of the orthopaedic nurses were their range age was40 years(21and over years old). In regard to marital status ,the majority of orthopaedic nurses (75\%) were married for the study group and $(60 \%)$ of control group orthopaedic nurses were married . This result was no influence on pin track infection of external fixation. The result is agree to the study by Nuha, et al ., ${ }^{(9)}$, who shoed the high percentage of orthopaedic nurses were married, the researcher suggested that the married orthopaedic nurses are not effect on their knowledge about pin track infection of external fixation in ward.

\section{Discussion of the mean of score for orthopaedic nurses knowledge related to pin track infection of external fixation for study and control groups with regard to the pretest (table 2):}

The results of table(2) the analysis of orthopaedic nurses knowledge related infection of pin track fixation are low to moderate items of mean of score for study group and have a low knowledge level with low mean of score of control groups of pre-test, this results agree with Ricardo who reported that orthopaedic patient and nurses was poor ${ }^{(10)}$. While A corner stone of pin infection of external fixation result less uses of aseptic technique, hand washing, un sterility of dressing around of pin and antimicrobial agent in orthopaedic.

\section{Discussion of the mean of score for orthopaedic nurses knowledge related to pin track infection of external fixation for study groups with regard to the post-test ( table 3):}

The results of table (3) the analysis orthopaedic nurses knowledge related infection of pin track fixation are low items in pre-test while high items in pre- test for study group after an educational program lecture, this result is agree with Linton, et $\mathrm{al}^{(11)}$ who mentioned the orthopaedic nurses knowledge have improved after the implementation of educational program about pin track infection for external fixation.

Discussion of the Mean of Score for orthopaedic nurses knowledge related to pin track infection of external fixation for study groups with regard to the pre-test and post-test between the Study Groups(table4): The results of table(4) the analysis orthopaedic nurses knowledge related infection of pin track fixation are low items to moderate in pre-test while high items in post- test for study group after an 
educational program lecture, this study finding that orthopaedic nurses knowledge have improved after the implementation of educational program about pin track infection for external fixation.

\section{Discussion of association between the study group post- test orthopaedic nurses knowledge related pin track infection for external fixation (Table5):}

Age: the data analysis of table (5) shows that there is no significant difference between total items rate of orthopaedic nurses knowledge related to pin track infection for external fixation with their age at $(\mathrm{P} \leq 0.05)$, this result disagree with shayma ${ }^{(12)}$ who stated that there was no significant relationship between orthopaedic nurses knowledge with age about pin track infection for external fixation.

Gender : the data analysis of table (6) shows that there is no significant difference between total items rate of orthopaedic nurses knowledge related to pin track infection for external fixation with their age at $(\mathrm{P} \leq 0.05)$, this result disagree with Maksimovic ${ }^{(13)}$ who demonstrated that there was no significant relationship between orthopaedic nurses knowledge and gender

Marital status : the data analysis of table (7) shows that there is no significant difference between total items rate of orthopaedic nurses knowledge related to pin track infection for external fixation with their age at ( $\mathrm{P}$ $\leq 0.05$ ), this result disagree with Nuha who reported that there was no significant relationship between orthopaedic nurses knowledge and Marital status

Educational level : the data analysis of table (8) shows that there is significant difference between total items rate of orthopaedic nurses knowledge related to pin track infection for external fixation with their age at $(\mathrm{P}$ $\leq 0.05$ ), this result agree with $\mathrm{Nam}^{(14)}$ who reported that there was a significant relationship between orthopaedic nurses knowledge and educational level.

\section{Conclusion}

From the present study findings, the researchers have got the following conclusions:

1-Ahigh percentage of orthopaedic nurses who work in orthopaedic ward were male at age group (30-39) years old , $35 \%$, and the similar percentage of the age in the control group was from orthopaedic nurses as percentage $50 \%$ of age group (30-39) years old .

2-the result of the study group are female and male similar percent with gender items in control group for each male and female.

3-Most of the result of the study level of education of orthopaedic nurses of the Study group are secondary school graduates while the great part of level of education of control groups had nursing medical institute graduates.

4-The majority of the orthopaedic nurses in study and control groups are married. The result percentage of married in study group of $(75 \%)$ and $(60 \%)$ of control group.

5-The mean of score findings for the study group indicate that there is a high orthopaedic nurses' knowledge related pin track infection for skeletal external fixation in the posttest period, while remains poor in the posttest for the control group. The findings of the study indicate that there is non-significant difference between (ages, gender and marital status) with orthopaedic nurses' knowledge of pin track infection of external fixation for the study group posttest).The findings of the study indicate that there is a significant difference between level of educational with orthopaedic nurses' knowledge of pin track infection of external fixation for the study group posttest.

\section{Recommendations}

The study recommends the importance of excessive information between orthopaedic nurses related pin track external fixation by distributed through standard or guide hand books to orthopaedic nurses, explanatory posters for external fixation devices, increasing activation programs from continuing educational units in each hospital through modern technology (audio-visual ). Encourage orthopaedic nurses to complete their academic study to provide efficient care and prevent infection of pin track for external fixation.

\section{References}

[1] Antoci, V.; Robert, C.; Antoci, J .: The Effect Of Trans fixation Wire Number And Spacing Between Two Levels Of Fixation On The Stiffness Of Proximal Tibial External Fixation : Orthopaedic Trauma, (2005), Pp(19,180.186).

[2] Behrens, F.: General Theories And Principles Of External Fixation, Clinical Orthopaedic pub med, 2000, vol. (15) no. (23), Pp. 241.

[3] Capo, T.; Swan,G. And Tan,v.: External fixation techniques for distal radius fractures, clinical orthopaedic, vol. 445, 2006, pp 33-40,

[4] Fattah, Am.: Surveillance Of Nosocomial Infections At A Saudi a Arabian Military Hospital , Germed Science , 2005,Vol.(3), No.(1), Pp 1-10. 
[5] Dahl,A. And Toksig,L.: Pin Site In External Fixation Sodium Chloride Or Chlorhexidine Solution As A Cleaning Solution , Orthopaedic Trauma Surgery , 2004, Volume .124,Pp .555-558.

[6] Mulhim, F.; Baragbah,A .;Ali, M.; Alomran,A.; Azam,Q.: Prevlance Of Surgical Site Infection In Orthopaedic Surgery:A5 Years Analysis, Int Surgery,2014,,Vol.99, No.3,Pp 260-270.

[7] Jadranaka,M.; Lijljana,Md.; Marko, B.; Jelena,M. And Hristin,V.: Surgical Site Infections In Orthopaedic Patients: Croatian Medical Journal , 2008, Vol.49, No.1, Pp 58-65.Avilable At Www.Cmj.Hr.

[8] Solomon, L . ; Warwick, D. and Naygam , S.: A pleys system of orthopaedic s and fractures: 59-Arnold an Hachette UK company, $19^{\text {th }}$ ed, 2010,pp (2-22) available http://www.hadderarnold.com.

[9] Noha ,El ;Berrie,M. And Et Al .:Coronary Artery Bypass Graft Surgery Patients In A Clinical Pathway Gained Less In Health Related Quality Of Life As Compared With Patients Who Undergo CABAG In A Conventional Care Plan, journal of evaluation in clinical

[10] Ricardio,j.; Pacheco, m. and saleh,m.: The role of external fixation in trauma, Arnold trauma, 2004,volume.6, pp 143-160.

[11] Linton, S., Van Tulder,M.: Preventive Interventions For Back And Neck Pain Problems ,Spine, 2001,vol.26,pp .778-787.

[12] Shymaa,M.: Effectiveness Of Instructional Program On Knowledge For Lumber Disc Prolapsed In Bagdad , journal of nursing and health science, 2016, vol.5, issue.4, pp.37-45.

[13] Maksimovic ; Denic,L. and Bumbasiveric, M.: Surgical Site Infections In Orthopaedic Patients :Prospective Cohort Study : The Creation Medical Journal , 2008, vol. 49,no.1, p58-65 available from www.CMJ.HR

[14] Nam ,S.: Evidence -Based Clinical Practice Guidelines For Care Of Pin Site Care In Orthopaedic Patient ,university of Hong Kong ,college of nursing ,2010,p.55. 